\title{
SOCIAL INVESTING AND THE LAW OF TRUSTS
}

\section{John H. Langbein* and Richard A. Posner**}

In October 1979 the United Auto Workers negotiated a threeyear labor contract with the Chrysler Corporation containing a provision that up to ten percent of new pension contributions would be invested in "socially desirable projects." The agreement defines these investments to include residential mortgages in areas where UAW members live, as well as investments in nursing homes, nursery schools, health maintenance organizations, and "other socially desirable projects." 1 The union also obtained the right "to recommend that pension trustees not invest in up to five companies that conduct business in South Africa."2 In Wisconsin and elsewhere there has been growing pressure to restrict large portions of the pension funds of state employees to investments in enterprises and mortgages in the state. ${ }^{3}$

These developments illustrate the increasing pressure on pension plan sponsors and fiduciaries to engage in what is called "social investing." 4 For the last year or two there has been hardly a month in which the industry journal, Pensions and Investments, has failed to carry some story about the demand on the part of a labor union or other group for social investing. As the Chrysler agreement indicates, these efforts have begun to get results. Similar pressures have been directed for an even longer time at the trustees of university endowment funds; some universities have yielded to those pressures

- Max Pam Professor of American and Foreign Law, University of Chicago. A.B. 1964, Columbia University; LL.B. 1968, Harvard University; LL.B. 1969, Ph.D. 1971, Cambridge University. - Ed.

* Lee and Brena Freeman Professor of Law, University of Chicago. B.A. 1959, Yale University; LL.B. 1962, Harvard University. - Ed.

The helpful comments of Fischer Black, Walter Blum, Kenneth Dam, Frank Easterbrook, James Lorie, Bernard Meltzer, Myron Scholes, and Rex Sinquefield on an earlier draft are gratefully acknowledged, as is the valuable research assistance of Judith Rose and Joseph Rugg.

1. 263 Pension Rep. (BNA) A-28 (Oct. 29, 1979).

2. $I d$

3. See D. Smart et. al., Investment Targeting: A Wisconsin Case Study 121-257 (Wisc. Center for Pub. Policy 1979).

4. For a good introduction to the debate over social investing, see EMPLOYEE BENEFIT Research Institute, Should Pension Assets Be Managed for Soclal/Political PurPOSES? (D. Salisbury ed. 1980). 
and have begun to utilize noneconomic criteria in the design of their portfolios, particularly with regard to the securities of companies doing business in South Africa.

In view of the growing practical importance of social investing, a careful examination of its economic effects and of its legality seems overdue, and we try to provide that examination in this Article. But we have first to define the term "social investing." We define it to mean excluding the securities of certain otherwise attractive companies from an investor's portfolio because the companies are judged to be socially irresponsible, and including the securities of certain otherwise unattractive companies because they are judged to be behaving in a socially laudable way. By "attractive" and "unattractive" we refer to the conventional objective of investment, which is to make money (in a slightly complex sense, explained in the next part of the Article) for the investment beneficiary. Not every practitioner of social investing would agree that there is a trade-off between social and more narrowly financial interests. Some would say that social investing is enlightened profit maximization. We evaluate this contention later. We also consider later another economic, as distinct from "social" (in a noneconomic sense), argument for social investing: that it confers a nonfinancial sort of utility on the investor by catering to his moral or political preferences. These qualifications are important. But, provisionally, the reader will not go far wrong if he understands social investing to be pursuit of an investment strategy that tempers the conventional objective of maximizing the investor's financial interests by seeking to promote nonfinancial social goals as well.

Our definition of social investing is narrow in one sense: we exclude the voting of shares, as distinct from the selection of which stocks to hold (or not hold) in the investor's portfolio, in accordance with social objectives. Social share voting has been proposed, ${ }^{5}$ and it, or its threat, has apparently achieved some modest sub rosa successes in deflecting management from profit-maximizing policies. ${ }^{6}$ We exclude it from our definition of social investing not because it is unimportant or uninteresting, but simply because it raises somewhat different legal ${ }^{7}$ and economic ${ }^{8}$ issues.

5. The most recent proposal is in Curzan \& Pelesh, Revitalizing Corporate Democracy: Control of Investment Managers' Voting on Social Responsibility Proxy Issues, 93 HARV. L. REv. 670 (1980):

6. See D. Vogel, Lobbying the Corporation 203-08 (1978).

7. The legal issues involve primarily the SEC's regulation of proxy voting.

8. Social share voting, to the extent successful in deflecting corporations from profit-maximization, is more costly to the investment beneficiary than social portfolio design because it 
We also pass over the broader question - of which social investing in both its portfolio-selection and its share-voting form might be thought but an aspect - of the social responsibility of corporations. ${ }^{9}$ The objective of those who advocate social investing is to make corporations behave in a socially responsible way by denying them capital if they do not. Therefore, if the debate over the social responsibility of the corporation is resolved in the negative, the social-investing issue is resolved as well. But as we shall see, social investing could be a bad idea, and a violation of trust law (and of the statutory counterparts to the common law of trusts, such as ERISA and the statutes governing investment by insurance companies), even if one thought it proper for corporations sometimes to subordinate profit maximization to other goals. The distinction justifies separate consideration of the social-investing issue. But we emphasize that the reader who has already decided that corporations should not be "socially responsible" need read no further.

Social investing could in principle be attempted by any investor, not just a trustee or other fiduciary. But the decision of an individual to include social goals among his investment objectives is not interesting from a policy standpoint and is not our focus in this paper. There are several small mutual funds which proclaim adherence to various social principles in selecting their investments. ${ }^{10}$ If an individual decides to invest in such a fund, presumably he has balanced the possible financial costs of such a policy against the util-

implies a capital loss, rather than a mere reshuffling of the investor's portfolio. There is also an inconsistency between social portfolio design and social share voting: the former implies that the investor should not buy into certain companies; the latter that he should buy into the same companies. The social share voter could accuse the social portfolio designer of selling his shares to just those who will not vote their shares in a socially responsible manner.

9. For a variety of perspectives on corporate social responsibility, see EcoNomICs of CoRporation Law and Securities Regulation ch. 13 (R. Posner \& K. Scott eds. 1980); Baumol, Business Responsibility and Economic Behavior, in ALTRUISM, MORALITY, AND ECONOMIC Theory 45 (E. Phelps ed. 1975); Chirelstein, Corporate Law Reform, in Soclal ReSPONSIBILITY AND the Business PRedicament 41 (J. McKie ed. 1974); Conard, Reflections on Public Interest Directors, 75 MICH. L. Rev. 941 (1977); Demsetz, Social Responsibility in the Enterprise Economy, 10 Sw. L. Rev. 1 (1978); Engel, An Approach to Corporate Social Responsibility, 32 StAN. L. Rev. 1 (1979). Cf. Arrow, Social Responsibility and Economic Efficiency, 21 Pub. Policy 303 (1973).

10. These are Foursquare, Dreyfus Third Century, and Pax World. Foursquare just avoids liquor, tobacco, and drug company stocks. According to its prospectus, Third Century limits itself (rather vaguely) to companies "contributing to the enhancement of the quality of life." Pax World excludes any company more than five percent of whose sales are to the Defense Department. See Pacey, Investment Do-Gooders: A Look at a Dogged Trio of Socially Conscious Mutual Funds, Barron's, July 21, 1980, at 9. Curiously, none of the three seems particularly interested in screening out companies that do business in South Africa, although that is the main objective of the social-investment advocates who complain about university endowment portfolios. See generally Stern, S. Africa Issue Stalls in Pension Area, Pension \& Investments, Sept. 24, 1979, at 19, col. 1. 
ity - a form of personal consumption - that he derives from expressing support for the social aims implied by the fund's investment policy. Few individuals have found the trade-off an attractive one, but we can think of no reason for prohibiting, or even discouraging, people from offering or purchasing such financial products.

A legal issue arises only when the investor or investment beneficiary has not consented to a decision by the investment manager to subordinate the investor's financial welfare to other objectives. In principle this could be a problem of individual trusts, as well as group trusts such as pension funds and charitable (e.g., university) endowment funds. But there has been little pressure on trustees of individual trusts to adopt social investing, so again this is not a focus of our analysis. The main purpose of the typical individual trust is to generate income for the immediate support of the current beneficiary (as opposed to the remaindermen, if any), who would be strongly inclined to protest if the trustee adopted an inconsistent goal. Also, many trust instruments authorize the beneficiary or the settlor to change trustees; such a provision tends to concentrate a trustee's mind wonderfully on profit maximization. In a pension fund, in contrast, most of the beneficiaries are not currently receiving income, so any adverse impact of social investing on the value of the trust assets will be felt in the future. ${ }^{11}$ Also, pension plan sponsors, such as labor unions, or corporations that bargain with labor unions about pension matters, are more exposed to the interest-group pressures that underlie, or at least influence the direction of, social investing.

For simplicity, we discuss the social-investing issue as if it arose in only four group-trust settings: a defined-contribution pension fund, such as that operated by the college teachers' pension fund; a corporate defined-benefit plan; a union-sponsored plan; and (in Part III of this article) a university endowment fund. ${ }^{12}$. This classification is not exhaustive, but it allows us to discuss the principal legal and

11. Employees who have retired and are receiving pension benefits may or may not be affected by social investing. They will not be affected if on retirement they received a lumpsum payment from the fund or were otherwise able to "cash out" or "roll out" of the fund. Even if they are affected, they are unlikely to receive as much attention from the pension fund as current employees; retired employees are no longer making contributions and hence cannot take their money elsewhere or persuade their employer to switch to another pension fund.

12. In a defined-benefit plan, the benefits to be received by the employee on retirement are specified in advance. The employer is responsible for paying these benefits, and the purpose of the pension trust fund is to assure that the employer has the assets to pay them in full even if the income from his business is insufficient. In a defined-contribution plan, the employee on retirement receives an amount determined by his and his employer's contributions plus accumulated income and appreciation on these contributions; he is not entitled to an amount specified in advance. 
policy issues presented by social investing. The defined-contribution fund presents the trade-offs between profit maximization and social investing in the simplest setting. The defined-benefit plan adds the wrinkle that most of the financial burden of social investing falls on the corporation rather than the employees. This apparent reallocation of financial burdens turns out to be more formal than real, but it does make a difference so far as the underdiversification caused by social investing is concerned. The union fund adds a different wrinkle: social investing (e.g., to preserve jobs) here may provide a pecuniary offset to the financial cost of departing from conventional investment strategy. The university endowment fund illustrates the social-investing issue in a context where the protection of retirement income is not at stake.

In Part I, after presenting a brief primer on the economics of securities markets, we analyze the economic and policy issues presented by social investing. We conclude that the usual forms of social investing involve a combination of reduced diversification and higher administrative costs not offset by net consumption gains to the investment beneficiaries. Social investing may therefore be economically unsound even though there is no reason to expect a portfolio constructed in accordance with the usual principles of social investment to yield ${ }^{13}$ a below-average rate of return - provided that administrative costs are ignored.

Part II relates our policy analysis to the law of trust investing. We conclude that the duty of loyalty, the prudent-man rule, and cognate doctrines, which govern both pension funds and trust investment generally, forbid social investing in its current form. But if the pension-fund beneficiary is allowed to opt out of any fund that practices social investment and into one that pursues investor financial welfare single-mindedly, social investing may be a reasonable and, under the ratification doctrine, legally permissible investment strategy for pension funds and related types of trusts. Part III extends our analysis to the university endowment fund, where the rights of individual beneficiaries do not hamper fiduciary investment decisions, but where a variety of other legal and practical hazards confront trustees who permit non-economic considerations to affect portfolio construction.

13. We define "yield" throughout this Article to include appreciation as well as dividends and interest. 


\section{The Economics of Social Investing}

We begin this part of the Article with a brief introduction to the economics of investing, meant for readers who are not familiar with modern portfolio theory. After deriving the optimal strategy for the investment manager to follow if his only concern is the financial well-being of the investment beneficiary or beneficiaries, we then consider how his strategy will be different - and with what consequences for the beneficiaries - if he decides to include in his investment strategy social goals distinct from the financial well-being of the beneficiaries.

\section{A. An Introduction to the Economics of Investing}

An investment decision involves two analytically distinct steps. ${ }^{14}$ The first is evaluating specific assets, such as the stocks of particular companies, that might be included in the investment portfolio. The other is combining specific assets to form the portfolio, which is the package of assets that is being managed for a particular beneficiary or beneficiaries.

Portfolio selection or design is critical because, from the standpoint of the beneficiary, who is the true owner of the investment, what counts is the performance of the portfolio rather than the performance of the individual components of the portfolio. If the portfolio as a whole rises or declines in value, the fact that the rise or decline is the summation of changes (possibly in opposite directions) in the value of the specific assets comprising the portfolio is of no moment. The portfolio is the relevant security.

The term "security" should be understood widely here, as including any asset that one might care to own. While the commonest securities are financial instruments such as stocks and bonds, nonfinancial assets such as real estate, a stamp collection, or a race horse could be part of an investor's portfolio. Because securities in the financial sense are the commonest investment assets, we shall use that term rather than the broader term "assets;" but our analysis applies regardless of the nature of the asset contained in the portfolio.

A security, including the composite security that we call a portfolio, has two dimensions: its expected return and its risk. The expected return of a security (or other asset) is straightforward: it is the

14. This section of the Article draws heavily on Langbein \& Posner, Market Funds and Trust-Investment Law, 1976 AM. BAR FoundATION RESEARCH J. 1 [hereinafter cited as Langbein \& Posner]. For a fuller introduction to the modern theory of finance, see selections in ECONOMICS OF Corporation LAW AND SECURITIES Regulation, supra note 9. 
sum of the possible benefits (including dividends, interest, appreciation, and, in the case of a nonfinancial asset, consumption benefits) to the security holder, multiplied by the probability that the benefits will actually materialize. So, setting to one side everything except appreciation in order to simplify the analysis, assume that a stock worth $\$ 10$ today is expected to be worth either $\$ 12$ or $\$ 14$ a year from now - that is, either $\$ 2$ or $\$ 4$ more - and there is a 50 precent probability of each outcome. Then the expected return of the security is $\$ 3(.5 \times \$ 2+.5 \times \$ 4)$.

Notice that the expected return would be the same if, instead of a 50 percent probability that the stock would be worth $\$ 12$ and a 50 percent probability that it would be worth $\$ 14$, there was a 100 percent probability that it would be worth $\$ 13$, or a 99 percent probability that it would be worth nothing and a 1 percent probability that it would be worth $\$ 1300$. In each case, the expected return is $\$ 3$. Therefore, if investors cared only about expected return, they would be indifferent to the different distributions of possible returns in the above examples. But suppose investors are risk averse - they do not like to gamble. Then the stock in the second example, which yields a certain return of $\$ 3$, is preferable to the first stock, which yields a range of returns from $\$ 12$ to $\$ 14$, and still more preferable to the third stock, which yields a range of returns from $\$ 0$ to $\$ 1300$. Economic theory implies and empirical study has confirmed that investors are generally risk averse, especially where substantial investments are involved. If we are dealing with a trust from which the beneficiaries derive a significant part of their present or future income, we can safely assume that they are risk averse.

Risk aversion implies, as we have said, a preference as between two or more securities having the same expected return for the one that yields this return with the least variance of possible returns about the mean or expected return. It follows that the risk averse investor will be willing to pay more for a less risky than for a more risky stock, even though the expected returns are the same. Stated otherwise, he will not pay as much for a riskier stock as he would for a less risky one having the same expected return. Suppose the expected per-share earnings of a company over some period, including appreciation, are $\$ 1$; there is no risk that the company will earn more or less than this figure; and the stock market capitalizes these earnings at a price-earnings ratio of ten, so that the price of the stock is $\$ 10$. It follows that if there is another stock which is expected to yield $\$ 1$ a share over the same period, but the stock may yield more or less than this amount, the market will capitalize the stock at a 
price-earnings ratio of less than ten. Once this happens, the investor will earn a higher expected return from the riskier stock. Suppose the price-earnings multiple of the less risky stock is eight. Then the stock will be priced at $\$ 8$, and its expected earnings will be 12.5 percent of its value. The riskless stock will be priced, we said, at $\$ 10$; it yields only 10 percent. The higher the risk, in short, the higher the expected return.

But this conclusion must be qualified in one important aspect, which requires us to distinguish between two types of risk - that which is diversifiable and that which is nondiversifiable (or systematic, as it is sometimes called). Diversifiable risk is that risk which can be eliminated by adding more securities to or changing the mix of securities in the portfolio; and it is the opportunity for diversification that makes portfolio design so critical a factor in investment strategy. The clearest example of diversification is where two stocks' earnings are perfectly negatively correlated. Suppose two firms have the pattern of returns assumed in our first example, i.e., a fifty percent chance of their share values rising from $\$ 10$ to $\$ 12$ and a 50 percent chance of their share values rising from $\$ 10$ to $\$ 14$, but suppose further that if one firm's better outcome occurs the other's worse outcome will occur; that is, if the first firm's share value rises to $\$ 14$, the second firm's will rise only to $\$ 12$, and vice versa. (Perhaps the first firm sells dental drills, and the second sells fluoride.) Then a portfolio consisting of an equal amount of each stock will yield a return of $\$ 3$ with certainty; there will be no risk. Assuming that it is no more costly to hold a portfolio consisting of both stocks than a portfolio consisting of only one of the two, neither stock will command any higher expected return in the market place than a stock which yields a certain return. In other words, diversifiable risk, the kind of risk involved in the stylized example just discussed, is not compensated risk; it does not command any higher return than a less risky stock yielding (before adjustment for risk differences) the same expected return. The reason is that no one will offer to sell a risky stock at a lower price than a riskless security if he can eliminate the risk, at no cost, simply by a change in portfolio design.

The returns to few if any stocks are negatively correlated, let alone perfectly negatively correlated. But neither are they perfectly positively correlated, and as a result portfolio risk can be reduced by diversification. By holding a portfolio that is diversified by region and industry, for example, the investor is buffered against certain sources of risk. To the extent that something which hurts one region or industry benefits another, the investor whose portfolio includes 
companies in both regions or industries will incur a smaller loss than if he were not diversified in this way. Conversely, the unexpected good fortune of one industry or one region will have a smaller positive effect on the value of the portfolio if the portfolio is diversified than if it is not, because in the former case the good fortune affecting one industry or region will tend to be offset elsewhere in the portfolio.

But not all risk can be diversified away, no matter how broad the portfolio. This is because the fortunes of firms tend to be positively correlated - they react in the same direction (though not to the same extent) to economy-wide events, such as decreases in aggregate demand or increases in interest rates. Risk that cannot be eliminated by diversification is called systematic risk and is illustrated by the day-to-day behavior of the broad stock indexes such as the Standard \& Poor's 500. The S\&P 500 is a diversified "portfolio" of common stocks, but of course it changes in value from day to day, implying the operation of forces that affect the stock market as a whole, as distinct from forces that merely alter the relative values of firms and whose effect on portfolio risk can therefore be eliminated by diversification.

Systematic risk can be reduced, though not through diversification. It can be reduced by increasing the proportion of assets in the portfolio that have below-average systematic risk, or even no systematic risk, such as short-term federal notes. But the investor pays a price; the expected return of such assets is lower than that of riskier assets, since risk averse investors will accept lower expected returns in order to reduce or avoid risk. The beauty of diversification is that it allows risks to be reduced or eliminated at a small cost - the cost of creating and maintaining a diversified portfolio. This cost is apt to be modest even for portfolios containing several hundred different stocks - at least, modest compared to the reduction in expected return that occurs when the investor changes the mix of the portfolio in favor of systematically less risky assets such as bonds and notes.

How far to go in diversifying one's portfolio thus depends on two things: the incremental reduction in risk from further diversification and the incremental administrative cost. There is debate among financial experts as to the optimal degree of diversification. Some believe that careful selection (stratified sampling) enables the major gains from diversification to be exhausted with a relatively small number of different securities, perhaps not more than 100 . Others favor portfolios consisting of thousands of different stocks, including those sold in foreign securities markets. We shall have more to say 
about optimal diversification later, when we consider some of the portfolio-design decisions of social-investing trustees.

The discussion thus far has assumed that the identity of the particular securities held in the portfolio is a matter of indifference to the investor pursuing an optimal strategy. When we said that the trade-off involved in deciding how far to go in diversifying the investment portfolio was between the gains from further diversification and the administrative costs of increasing the number of securities in the portfolio, we implicitly excluded, as a possible cost of diversification, the forgone opportunities in exceptional performance which extensive diversification necessarily involves. The more diversified a portfolio, the less impact a shrewd decision to sell an overvalued stock or to buy an undervalued one will have on the value of the portfolio; the effect of the shrewd choice will be diluted by the fact that the stock in question will have only a small weight in the portfolio as a whole if the portfolio is indeed highly diversified.

We must therefore consider whether an alternative to diversification as a means of increasing investor utility may not be to exercise greater care in the selection of a smaller number of securities, so that the expected return of the portfolio will exceed that which could be expected from holding a larger number of securities. We must consider, in short, whether "stock picking" is a profitable investment strategy. Restated, the question is whether the costs of stock picking - which include not only the research and trading costs involved in an active strategy, but also the sacrifice of diversification that is entailed in concentrating one's investment assets in those stocks expected to outperform the market average - are likely to be more than offset by the higher expected return that can be obtained by careful selection among the array of alternative securities within any given class (common stock, for example) of investment asset.

It may seem self-evident that a skilled investor, who conducts careful research into the conditions and prospects of particular companies and of the economy as a whole, will earn a higher return (correcting for any difference in systematic risk) than the investor who simply "buys the market," blindly investing in the entire stock-market list and never selling a stock when its prospects begin to sour. But, on reflection, this proposition really is not self-evident. There is, to begin with, the inherent difficulty of forecasting the future. Since the value of a stock is mainly a function of its anticipated earnings, and therefore depends primarily on events occurring in the future, it will often be impossible to determine whether a stock is undervalued at its current price without knowing what the future 
holds. As for the stock that is undervalued because of some characteristic of the company (or of its competitors, suppliers, customers, political environment, etc.) that is not widely known or correctly interpreted, the problem is that the underlying information is in the public domain. (If it is not in the public domain - if it is "inside" information - it cannot lawfully be used for purposes of buying or selling stock, and presumably the law has some deterrent effect.) Information in the public domain is equally available to all security analysts. The only way of making money from such information is to interpret it better than the other analysts. This is not a very promising method of outperforming the market; it requires both that the analyst's interpretations of publicly available information differ from the average opinion of the analyst community and that his deviant interpretations be correct substantially more often than they are incorrect.

Thus it is not surprising that studies of the mutual fund industry have found that the funds, despite their extensive employment of security analysts and portfolio managers for the purpose of outperforming the market, do not outperform it. They do no better than the blind "market portfolio." To this it may be replied that the proper comparison is not between all mutual funds and the market but between the most successful mutual funds and the market. But the studies show that there are almost no consistently successful mutual funds. Naturally, some enjoy shorter or longer runs of success, but the degree of success observed is no greater than one would expect if luck, not skill, was the only factor determining the fund's performance.

The study of money managers has focused on the mutual funds because they are required by federal law to report in detail on their performance, thus affording a large data base; but there is every reason to believe that common trust funds, pension funds, and other institutional investors likewise fail to outperform the market portfolio. Paul Samuelson has concluded that there is ample reason for doubting whether even "the best of money managers" are "capable of doing better than the averages on a repeatable, sustainable basis." 15

The studies support an even stronger conclusion: when brokerage costs and management fees are taken into account, the average mutual or common trust fund yields a significantly lower net return than a fund keyed to a broadly based market index such as the S\&P

15. Samuelson, Challenge to Judgment, J. Portfolio Management 17 (Fall 1974). 
500. This comparison was long derided on the ground that the $S \& P$ 500 is a hypothetical fund and hence has no administrative costs. Now that there are some real market funds in operation, it is possible to evaluate - and reject - this criticism. The administrative costs of a market fund turn out to be so low (on a $\$ 500$ million portfolio, they would be no more than eleven percent of the costs of conventional management) that the net returns of a properly constructed market fund are only trivially different from those of the hypothetical market portfolio. The administrative costs are low because the management of a market fund does no securities analysis and very little trading (just enough to handle redemptions and maintain the desired level of diversification of the fund). In short, a passive, market-matching fund is likely to outperform a conventional, activelymanaged fund in terms of expected return; in addition, it is much more diversified than a conventional fund. On both counts, it yields greater utility to the investor. ${ }^{16}$

Having outlined in this section of the Article the optimal investment strategy for an investment manager concerned solely with the financial well-being of his (risk-averse) investment beneficiary, we consider in the next the modifications of the strategy that are necessary if the manager decides to embrace a social-investing strategy as a substitute for or supplement to a strategy of maximizing investor financial well-being (as we have defined that concept in terms of expected return and of risk). We shall also consider to what extent our analysis must be modified if some of the more controversial aspects of the theory of finance presented in this section are rejected.

\section{B. Portfolio Adjustments by the Social Investor}

It is not easy to specify the portfolio adjustments that an investor committed to social investing would have to make, because the social principles are poorly specified. There is no consensus about which social principles to pursue and about which investments are consistent or inconsistent with those principles. At a time when most of the social activism in investing was liberal or radical rather than conservative, there was some agreement among the activists as to the types of companies that should be avoided and the types that should be embraced. The ranks of the disapproved included companies lending to or having branches or subsidiaries in the Republic of South Africa, big defense contractors, nonunion companies, and

16. For the evidence supporting the assertions in the above discussion, see references in Langbein \& Posner, supra note 14, at 6-18; and for reply to criticisms, Langbein \& Posner, Market Funds and Trust-Investment Law: II, 1977 AM. BAR FOUNDATION RESEARCH J. 1. 
prominent or recurrent violators of federal discrimination, pollution, safety, and antitrust laws. More recently, the nuclear power and herbicide industries have also fallen into disfavor. The ranks of the approved included companies that manufactured anti-pollution equipment, or used especially clean technologies, or invested in the inner cities. Most of the literature on social investing discusses the portfolio adjustments that must be made by an investment manager who follows the list of exclusions and inclusions recommended by liberal and radical spokesmen. We shall do the same for want of any practical alternative, while emphasizing the arbitrariness of these conventions even as a litmus of activist thinking. With the rapid rise of right-wing social activism, we can expect social-investment advocates to appear who will urge investment managers not to invest in corporations that manufacture contraceptive devices, or publish textbooks that teach the theory of evolution, or do business with the Soviet Union. And with the growing concern about the military strength of the Soviet Union relative to the U.S. - a concern not limited to right-wing extremists - a desire to penalize companies for having large defense contracts no longer has the appeal it once did. There is also increasing awareness that the criteria used to identify socially irresponsible companies are dubious even if the ultimate objective - say, getting the Republic of South Africa to abandon apartheid - is accepted. A U.S. corporation that has a plant in South Africa where it engages in collective bargaining with a black union is not obviously contributing more to the perpetuation of apartheid than an American corporation that, without having an office in South Africa, manufactures goods that find their way to South Africa. ${ }^{17}$

These complications to what once seemed, at least to social-investing advocates, clear-cut criteria of portfolio exclusion and inclusion make it difficult to describe the typical portfolio constructed in accordance with social principles, and hence to determine the portfolio adjustments required to bring an investment portfolio into conformity with those principles. However, even without attempting to describe the typical social-investment portfolio, we can offer a few observations on the probable characteristics of such a portfolio and on the consequences of those characteristics for the investment beneficiaries' financial well-being.

17. For a powerful criticism of social investment along these lines see Schotland, The $O_{p}$. ponent's Arguments: A Review and Comment, in SHOULd PENSION ASSETS BE MANAGED FOR Social / Political PuRposes?, supra note 4, at 105. Schotland's essay has been reprinted in Trusts \& Estates in several parts. See especially Schotland, Should Pension Funds Be Used To Achieve "Social" Goals? (Pt. 2), Trusts \& Estates 27 (Oct. 1980). 
1. A portfolio constructed in accordance with social principles will be less diversified than a portfolio constructed in accordance with the optimal strategy of portfolio design described in the previous section. This is because stocks are added to and subtracted from the portfolio by the social investor without regard to the effect on diversification. To be sure, if social responsibility were a random characteristic of firms, so that the set of socially responsible firms differed from the set of socially irresponsible firms only in respect to social responsibility, and not in size, profits, location, or other relevant financial characteristics, the effect on diversification of excluding the socially irresponsible firms from the investment portfolio would be limited to what is called sampling error. That is, one could not draw so large a sample from the underlying universe of firms if some of the firms were ineligible for inclusion in the sample. For example, if one wanted to have a portfolio consisting of ninety percent (by value) of the firms on the New York Stock Exchange, and twenty percent of such firms were deemed socially irresponsible and hence ineligible for inclusion in the portfolio, exclusion would create more sampling error than desired, and therefore diversification would be less than desired.

If socially irresponsible firms are not a random draw from the underlying universe of firms, then the use of social-investing criteria to design the portfolio will result not only in sampling error, but also in sampling bias. One can approximate the performance of the stock market as a whole by an approximately randomized (including stratified) sample that is much smaller than the market as a whole, but it is much harder to approximate the performance of the market if the sampling procedure is nonrandom. And a sampling procedure that involves first excluding firms deemed socially irresponsible is not a random sampling procedure, because the set of such firms is not a random draw from the universe of firms. Firms deemed socially irresponsible tend to be disproportionately large firms, and they tend to be concentrated in particular regions and industries. For example, the South would be underrepresented in a sample limited to socially responsible firms because firms located in the South are more likely to be deemed anti-labor and excluded from the socially responsible portfolio on that ground than firms located elsewhere in the U.S.

The bias imparted by social investing interacts with the problem of sampling error in the following way: a large firm is, by virtue of its size, less likely to survive social-investing screening than a small one, but the exclusion of a large firm from the investment portfolio has a bigger effect in creating sampling error than the exclusion of a 
small firm. This is because the large firm has a greater weight in the overall performance of the market, and it is that overall performance that one is seeking, through diversification, to track as closely as possible.

If one asks why large firms are more likely to be "fingered" as socially irresponsible than small ones, the answer is not that large firms contain a higher proportion of wicked people than small, or engage in a higher proportion of wicked acts. It is rather that, simply by virtue of being large, they do more wicked acts or contain more wicked people (as well as more people pursuing virtue). But if ten small firms cause as much human suffering as one large one, ethical principles hardly justify punishing the large firms and not the small firms. Indeed, it is probably the case that wickedness is proportionally more prevalent among small firms than among large, simply because law enforcement efforts, journalistic muckraking, and other activities that result in the exposure of illegal or immoral acts are concentrated on large firms.

Our discussion of sampling error and sampling bias has been qualitative rather than quantitative. To measure the amount of underdiversification to which social-investing would give rise would require an initial specification of the social-investing portfolio. At one extreme, in a portfolio composed of the S\&P 500 weighted by the relative market value of the total outstanding shares of each stock, the discarding of half a dozen small firms, amounting in the aggregate to one-tenth of one percent of the total market value of the S\&P 500 , would have only a small effect on the diversification of the portfolio. The effect would be even smaller if the original portfolio was broader than the S\&P 500. At the other extreme, consider an investment manager who decided that social principles required him to discard the stocks of all defense contractors, all adjudicated violators of health, safety, antitrust, or discrimination laws, major oil companies, all firms doing business with any nation in which there were serious violations of human rights, all liquor and tobacco companies, and even all firms that invest abroad ("export jobs"). ${ }^{18}$ The removal of all such firms from a portfolio of common stocks would result in a seriously underdiversified portfolio.

There have been several studies of the effects on diversification of the intermediate level of exclusions that typifies the mutual funds and university endowment funds that have embraced the concept of

18. This last suggestion appears in Ruttenberg, Friedmen, KILGallon, Gutchess \& Associates, Inc., AFL-CIO Pension Fund Investment Study 57 (Wash., D.C., Aug. 20, 1980). 
social investing. The principal exclusions considered in these studies are firms having branches or subsidiaries in the Republic of South Africa. There are many such firms, including many of the largest firms in the market, ${ }^{19}$ and the effects on diversification of casting them out of the investment portfolio are, therefore, not trivial. But because most of the gains from diversification can be achieved with a portfolio significantly smaller than the market portfolio or some approximation thereto such as the S\&P 500, it is possible that a portfolio could be constructed in which a significant fraction of the largest U.S. firms were ineligible for inclusion yet which was not grossly underdiversified. ${ }^{20}$

But would a consistent and principled devotion to the concept of social investing allow the manager to stop with such comparatively modest exclusions as those described above?21 If one wants to place economic pressure on the government of the Republic of South Africa, the good pressure points are not limited to firms having branches or subsidiaries there. Getting AT\&T to sever telephone service with South Africa, or U.S. banks to refuse to honor checks drawn on South African banks, would be more efficacious than getting U.S. firms to close their offices in South Africa. This implies the desirability of refusing to hold the stocks of these companies as a means of bringing pressure on them to stop dealing with South Africa. But if this point is accepted, the social-investing advocate will have to argue for much greater portfolio exclusions than those discussed above.

Furthermore, while the Republic of South Africa may be an iniquitous society, it is not unique in this respect. We find it difficult to condemn more severely a society in which 80 percent of the inhabitants lack political and civil rights than the many societies in which 99 percent of the inhabitants are in this position. It will not do to say, with Yale's Ad Hoc Committee on South African Investments: "We acknowledge the possibility that the policies of other governments throughout the world are equally antagonistic to the basic principles of American society and this University; if so, then our

19. See Rudd, Divestment of South African Equities: How Risky?, J. PoRTFolio MaNageMENT 5, 6 (Spring 1979).

20. See Rudd, supra note 19; Emery \& Hawkins, Sound Fund Management Allows Some Social Considerations, ARIZ. REv. 1 (Oct. 1973); S. BALDWIN, J. TOWER, L. LITVAK \& J. KaRPen, Pension Funds and Ethical InVestment: A Study of INVESTMEnt Practices AND Opportunities, State of California Retirement Systems 103, A1-A2 (Council on Economic Priorities, New York City, 1980) (effect on diversification of excluding 132 U.S. corporations doing business in or lending to the Republic of South Africa).

21. For a good discussion of this question, see Malkiel \& Quandt, Moral Issues in Investment Policy, HARv. Bus. Rev. 37 (March-April 1971). 
recommendations concerning South African investments should be applied to them." 22 It is not a possibility that there are other such societies; it is a certainty. (At the time that the Ad Hoc Committee wrote its report, the Amin regime was still in power in Uganda and the Pol Pot regime in Cambodia.) What the Committee seems to be saying, if one reads between the lines, is that it will not consider further applications of the social-investment principle until some group raises as great a stink as the opponents of the South African regime have raised. This approach makes social investing a branch of interest-group politics.

In sum, we are skeptical that a portfolio constructed in accordance with consistent, and consistently applied, social principles could avoid serious underdiversification. In 1979, Corporate Data Exchange, Inc. identified ninety-nine companies that a socially responsible investor should avoid. The aggregate market value of the stocks of these companies was $\$ 342$ billion. Yet the only criteria for exclusion were whether the company was predominantly nonunionized, had a poor record in occupational health and safety, failed to meet equal employment opportunity guidelines, or was a major investor in or lender to South Africa. ${ }^{23}$ Although this is an arbitrarily limited set of criteria, it results in excluding such a large fraction (weighting numbers by market value) of listed equities as to create a degree of sampling error and sampling bias inconsistent with adequate diversification of the portfolio. Stephen Manus and David Steirman of American National Bank of Chicago, under the direction of Rex Sinquefield, Executive Vice-President of the bank, at our request attempted to construct a portfolio of common stocks that would be optimally diversified, subject to the constraint that the ninety-nine firms designated by Corporate Data Exchange be ineligible for inclusion in the portfolio. They constructed a portfolio of 163 stocks, carefully selected to offset so far as possible the biases introduced by excluding the ninety-nine stocks. The portfolio they constructed contained 2.1 percent more residual risk than the S\&P 500. What that means is that whatever the return of the S\&P 500 might be in a particular year, the portfolio they constructed - a socially responsible portfolio by the standards of Corporate Data Exchange would have a five percent probability of being 4.2 percent or more higher or lower, and a one percent probability of being 6.3 percent or

22. Yale University, Ad Hoc Committee on South African Investments, Report TO THE CORPORATION 4 (April 14, 1978) (on file with the Michigan Law Review).

23. See Corporate Data Exchange, Inc., CDE Handbook: Pension Investments, A SocIAL AUDIT 8-11 (1979). 
more higher or lower, than the return of the S\&P 500. Stated otherwise, in any given year one in twenty socially responsible investors would be expected to deviate from the performance of the S\&P 500 (itself but an approximation of the fully diversified market portfolio) by more than 4.2 percent. We think this is a substantial increment in risk.

We leave to the moral philosophers to advise us whether a portfolio constructed in accordance with the suggestions of Corporate Data Exchange or any other proponent of socially responsible investing would indeed be socially responsible. It seems to us that the list of ninety-nine is arbitrary. To this it may be replied that it is appropriate to trade off moral gains from excluding more and more socially irresponsible firms against the financial costs, in increased portfolio risk, of doing so. Assuming such trade-offs are morally permissible or attractive, we nevertheless point out that both the costs and the benefits of social investment are positively related to the extent to which the principles of social investment are pursued in a serious and consistent fashion. If only token exclusions from the portfolio are made, the costs in underdiversification are slight but so are the social or moral benefits of social investment. As more and more companies are excluded, the benefits in conforming to consistent and serious principles of social investment are increased but so are the costs in increased portfolio risk. The Corporate Data Exchange list of ninety-nine illuminates the nature of the trade-off by showing that, even when exclusion is arbitrarily limited to a subset of the plausible candidates for exclusion (arbitary given the underlying values and principles of the proponents of social investing), substantial costs in increased portfolio risk are incurred.

The type of social investing espoused by some union, and some state and local government employee, funds requires separate consideration under the head of diversification. ${ }^{24} \mathrm{~A}$ union pension fund that decided to avoid investing in any stock issued by a nonunionized company would be imparting a pronounced regional bias to its portfolio, because unionized companies are concentrated in the nation's declining industrial base in the northeastern and midwestern

24. For a defense of this form of social investing, see D. SMART, supra note 3; for recent developments in this area, see Epstein, Illinois Group Recommends Funds Adopt Social Criteria, Pensions \& Investments, June 23, 1980, at 3; Minick, Social Investing Sparks N.Y. Fund Debate, id. Sept. 24, 1979, at 1; Scott, Sacramento Unions Blast 'Social' Concept, id., Nov. 5, 1979, at 1; Sojacy, Bill Limiting Public Fund Stock Holdings Introduced, id, June 23, 1980, at 3; Stern, Unions Band Together To Discuss Other Uses for Pension Assets, id, April 28, 1980, at 4; Stern, Drexel To Use Social Criteria To Invest, id., Sept. 10, 1979, at 1. Prudential Insurance Company has recently announced a pension investment fund limited to "mortgages of projects built by union labor." Wall St. J., Dec. 9, 1980, at 19, col. 1 (Midwest ed.). 
states. Even worse effects on diversification would be caused by a decision to concentrate the fund's assets in one state or region: in Michigan, for example, which has been so hard hit by the recent near collapse of the domestic automobile industry. Or suppose that a school board in the vicinity of Mount St. Helens had insisted on investing locally.

We consider that the larger danger to adequate diversification lies not in what might be called the ideological version of social investing, which has been characterized by tokenism, but rather in the seemingly "practical" version that seeks to use employee retirement assets to enhance the employment security of employees who have not yet retired. To be sure, the costs in reduced diversification might be offset by gains in enhanced employment security for nonretired employees; but we think this unlikely. Suppose an employer is threatening to move his plant to another region of the country because his labor costs, which include both pension costs and wages (as well as other fringe benefits), will be lower there. To induce him to stay, the union might be tempted to furnish him with capital at attractive rates by lending from the union pension fund beyond the level that a prudent regard for portfolio risk would indicate; but equally it could agree to a reduction in some other fringe benefit, or to a reduction in wages. Many workers, if asked whether they would prefer, in response to adverse conditions in the industry in which they were employed, a lower wage while working or a less secure retirement, would choose the lower wage. The alternative, a less secure retirement, is often attractive to labor unions because they are dominated by current rather than retired workers, and so would rather transfer wealth from retired workers than from current workers. ${ }^{25}$ By increasing the risk or reducing the solvency of the fund assets, the union can place the heaviest costs of social investing on those workers - the retired ones - whose current income is generated by the fund assets. Active workers' expected retirement benefits are also reduced, perhaps substantially, but against this future loss is set a present gain, in which retired workers do not share, in greater employment security.

When the pension fund is not a defined-contribution plan (where, as mentioned earlier, retirement benefits fluctuate with the

25. The Taft-Hartley Act imposes some limit on this tendency by requiring that employee benefit plans established jointly by a union and one or more employers be administered by equal numbers of union and of employer-designated trustees (together with any "neutral" persons that they choose to co-opt). Labor Management Relations Act $\$ 302(\mathrm{c})(5), 29$ U.S.C. $\S 186(c)(5)(1976)$. 
performance of the fund) but instead a defined-benefit plan (where an employer, or employer group, contracts to provide a specified level of benefits), the analysis is altered slightly. If a corporation having a defined-benefit plan decides to invest in the local community without regard to the soundness of the investment, most of the resulting risk is borne by the corporate shareholders rather than the pension fund beneficiaries. The latter are hurt only to the extent that the solvency of the corporation, and hence its ability to meet its contractually defined obligations to retired workers, is impaired. ${ }^{26}$ To be sure, a corporation that anticipates that its employees, their unions, or the local community will pressure it into making suboptimal investments will treat the resulting risk as a cost of employment and shift it to the workers. But the defined-benefit feature will tend to buffer the effect on retired workers. Moreover, the amount of risk imposed on the corporation, and hence the amount of cost it will try to pass on to its employees, will tend to be slight. ${ }^{27}$ When the entire corporation is viewed in the financial sense as a portfolio of assets, the pension fund is only one corporate asset, and if it is underdiversified, this can be offset by adjustments in the other assets of the corporation. And from the standpoint of the corporation's shareholders, even if this one stock in their portfolios has been made riskier as a result of the corporation's pension-investment policy, this will have little effect on their overall portfolio risk so long as the shareholders hold well-diversified portfolios.

Thus far we have been discussing common stock funds, rather than bond funds or mixed stock and bond funds. The problem of diversification is less acute in the case of bonds than in the case of stocks, because the variance in the performance of bonds across companies (we are not speaking here of variance due to changes in interest rates, which affect all bonds of the same maturity) is much smaller than in the case of stocks. Stated otherwise, by holding bonds instead of or along with stocks in one's portfolio, one accomplishes by another means the objective of diversification, which is to reduce variance in yield. Therefore, to the extent that the concept of social investing is applied to bonds as well as stocks, the result will be some cost in reduced diversification of the bond component of the

26. ERISA's pension insurance and guarantee arrangements contemplate that much of this risk will be shifted to the other employers in the insurance system, and in the last resort to the federal treasury. See 29 U.S.C. $\$ \$ 1301-23$ (1979).

27. See Black, The Investment Policy Spectrum: Individuals, Endowment Funds and Pension Trusts, Financial ANalysts' J. 3, 9 (Jan.-Feb. 1976). 
portfolio, but the cost will be less than in the case of the stock component.

2. We may seem to have dwelled at excessive length on a rather esoteric effect of social investing - the reduction in diversification - and to have ignored what might appear to be the larger effect on the investment portfolio - the effect on the rate of return - of excluding many successful companies and including many less successful companies. In fact, the modern theory of finance undermines the notion that portfolio selection based on social, or on any other, principles will affect the expected or average return of the investor, net of administrative costs. If stock picking is futile, then every stock (of the same risk class) is an equally good investment ex ante. Therefore, even if adherence to social principles biased the investor's portfolio in favor of unprofitable or financially precarious companies, the expected return of the portfolio would be the same as that of portfolios managed in accordance with a sole objective of investor wealth maximization. If a firm's expected earnings are low, the price of its stock will be bid down by the market to the point where it yields the same expected return to the shareholder as any other stock having the same systematic risk. If it yielded a lower return, no one would buy it, and the issuer (or current holder) would have to reduce price until the expected return to the purchaser was equal to what the purchaser could get elsewhere. Even if a firm is bankrupt, its stock will command a positive return so long as it has any prospect of yielding a positive return to shareholders through reorganization or liquidation, and it will be priced at a level that will yield the same expected return to the purchaser as that of a blue chip, correcting for any difference in systematic risk. ${ }^{28}$

Hence we are not concerned that adherence to social principles will result in portfolios that yield lower average returns than portfolios designed to maximize the financial well-being of the investment beneficiaries. The average return will be the same - a prediction of theory that is consistent with the (very limited) empirical studies that have been made of social-investment portfolios. ${ }^{29}$ By the same token, we reject the argument that the social investor can consistently pick winners by being more sensitive to political and social factors that can impinge on corporate profitability. This is just another the-

28. See Langbein \& Posner, supra note 14, at 17-18.

29. Pacey, supra note 10 , finds that the three mutual funds that follow a social-investment strategy have done better than the average of mutual funds during the period in which these funds have been operating. But she presents no evidence that this performance is due to anything other than luck, or possibly a higher systematic risk of the funds' portfolios. 
ory of how to beat the market, and it has no firmer basis than any other such theory. If, however, the theory were correct, the issue of social investing would not be worth discussing, at least by the likes of us; it would be a tactic for maximizing investor financial well-being, and we would leave it to the finance theorists and investment professionals to determine whether it was a good tactic. Finally, if we are wrong that stock picking is a futile strategy for pension fund trustees to follow, and if social investing is not just another theory of how to beat the market, or is not a good such theory, then, to the costs of underdiversification which social investing, consistently pursued, gives rise, would be added another cost: the forgone gains from following a better theory of how to outperform the market.

3. Our conclusion that a social-investing portfolio will probably have the same expected return as a standard investment portfolio (of the same systematic risk) requires qualification in one respect: the administrative costs of a social-investment portfolio will be higher, and the net expected return therefore lower, than the administrative costs of a portfolio constructed in accordance with the principles of modern finance theory. The strategy of the latter portfolio is, as already explained, a passive one, and it reduces management and trading costs to negligible levels. The portfolio manager buys and sells securities only to maintain the desired amount of diversification ${ }^{30}$ (and these trading costs generate more than offsetting gains in reduction of portfolio risk). And he engages in no securities analysis at all. In contrast, the social investor, in proportion to how seriously he takes his self-imposed duty to screen out socially irresponsible companies and screen in socially responsible ones, incurs costs both of securities analysis (albeit of an unconventional kind, since the focus is not on the company's income prospects but on monitoring its compliance with the investor's social aims), and of trading; stocks will be added to and subtracted from the portfolio with changes in the issuing corporation's policies and in the conception of what social investing requires.

An interesting point emerges from this discussion: while the social-investing strategy generates higher administrative costs than the passive strategy prescribed by the theory of finance, it need not generate higher administrative costs than an investment strategy that involves research and active trading. The administrative costs are

30. Out of an abundance of caution, most "index" funds screen out of their portfolios firms in danger of going bankrupt. There is no sound economic reason for the practice, other than to minimize legal risk (see Langbein \& Posner, supra note 14, at 26-38), but it is common, and it does increase the costs of management and trading above those of the pure index fund. 
incurred in slightly different activities, because the investor who is trying to "beat the market" and the social investor are looking for different attributes in the companies in which they invest; but it does not follow that administrative costs are higher in one type of active strategy than the other. At a guess, research costs would be higher under a social-investing approach if the investment manager took seriously his obligation of social investing, and trading costs higher under a beat-the-market strategy. Although the net effect is difficult to predict, one thing seems clear: an investor who tried to combine social investing with conventional wealth maximizing would incur the highest administrative costs of all. A related implication of our analysis is that the investor who is passive and does not attach much importance to diversification will not obtain, on average, any better results than the social investor, in terms of risk, return, or administrative expense, unless the social investor carries exclusion to the point where his portfolio is even less diversified than the investor who does not attach great importance to diversification. But there are few fiduciaries who do not value diversification highly. ${ }^{31}$

4. Thus far we have considered only the conventional investment attributes of the socially responsible investment portfolio - risk and diversification, return, and management and brokerage fees. The social-investment strategy is inferior in these attributes to the optimal strategy prescribed by the modern theory of finance. But perhaps social investing confers a compensating utility on the investor. An analogy can be drawn to the ownership of works of art. There is both a consumption and an investment aspect to such ownership. Historically (except in very recent times), the rate of return on investments in art has been lower than that on "pure" investments such as common stocks. ${ }^{32}$ The fact that people were nevertheless willing to invest in art reflected the fact that they obtained consumption value from their investment which, when added to the investment return, equaled or exceeded their alternative investment and consumption opportunities. It is not only possible, it is strongly implied by economic theory, that people who choose to invest in mutual funds dedicated to social investing derive a consumption value from their investment, since the pure investment value is, at least on an expected basis, inferior to that of alternative investment vehicles.

But this presumption fails when the investor lacks a free and informed choice among investment vehicles, which is the practical sit-

31. See Langbein \& Posner, Market Funds and Trust-Investment Law: II, 1977 AM. BAR. Foundation RESEARCH J. 1, 24-28.

32. See Stein, The Monetary Appreciation of Paintings, 85 J. Pol. EcoN. 1021 (1977). 
uation in which many pension-fund beneficiaries find themselves. Even if pension-fund trustees adhered steadfastly, and for long periods, to clearly articulated standards of social investing, the choice of an individual as to what occupation to enter, or what employer to work for, would probably not be materially influenced by his agreement or disagreement with the announced standards of the relevant pension fund managers. It would be especially unlikely when the pension fund covered an entire industry, as is virtually the case with some of the so-called Taft-Hartley plans, or with the college teachers' pension fund. ${ }^{33}$ Thus, social investing imposes disutility on many pension fund beneficiaries at the same time that it confers utility on others. Because there is no practical mechanism by which pension fund trustees can make the felicific calculations necessary to decide which social principles they should adopt in order to maximize the overall utility of the fund beneficiaries, ${ }^{34}$ there is no basis for a judgment that the positive consumption aspects of social investing will on average exceed the negative. If the consumption aspects are assumed to be a wash, then one can conclude that social investing involves a probable reduction in the overall wealth or utility of investors, compared to an investing strategy that focuses exclusively on maximizing the financial well-being of investors.

But this analysis is probably sound only if the disutility resulting from the pension fund trustees' decision to pursue social investing (or what social objectives to set) is small on an individual basis. If it is large, then employees will sort themselves among employers in accordance with the pension fund policies on social investing followed by the employers. In truth, our whole analysis implies that the disutility of social investing to the individual investment beneficiary will tend to be modest. The fund dedicated to social investing will be less diversified and more costly administratively than the fund which follows the optimal strategy, and these are sources of disutility, but the difference in overall performance should not be great - and anyway most pension funds probably do not follow the

33. To be sure, in principle a worker who disliked the social principle followed by his pension fund would demand a higher wage in compensation; but union rules against wage differentials among workers of the same seniority doing the same job would prevent such a compensating adjustment, at least in the unionized sector. Nor would a university, for example, agree to pay a higher wage to teachers offended by the social principles adopted by the teachers' pension fund - the university would find it impossible to determine the sincerity of the teachers' protestations.

34. The difficulty pension fund trustees face in trying to determine the social-investing preferences of the beneficiaries is acknowledged in Ferguson, The Advocate's Arguments: $A$ Review and Comment, in Should Pension Assets Be Managed for Social/Political PURPoses?, supra note 4 , at 94, 100-03. 
optimal strategy, at least as taught by the modern finance theorists, but instead adhere to the inferior strategy associated with trying to beat the market, at the price of heavy administrative expenses and underdiversification. Of course, some individual employees will be offended by the choice of social-investing objectives of their pensionfund trustees - provided they know what those objectives are - but the disutility resulting from such offensiveness is probably small for most people, and if it is great for a particular employee, then, as mentioned, he will go elsewhere. We conclude that the disutility to the individual investment beneficiary from social investing will normally be small, but the sum of these disutilities across all the affected individuals may not be small, which supports our conclusion that when all relevant factors are considered, it is probable that social investing results in a net diminution of the overall utility of the investment beneficiaries.

It is consistent with this analysis, however, that a mode of social investing which preserved the freedom of choice of investment beneficiaries might confer greater net benefits than a refusal to offer anything but the strategy that maximizes purely financial well-being. We explore in the next part of this Article the feasibility of such a "check-off" 35 system under the ratification doctrine of trust law.

\section{Is Social Investing Lawful for a Trustee?}

\section{A. General Analysis}

We have argued that social investing is undesirable because it appears to reduce the overall utility, however broadly defined, of the investment beneficiaries. It remains to consider whether social investing is contrary to trust law and its statutory counterparts. We conclude that it is (except in the optional format discussed later); a trustee who sacrifices the beneficiary's financial well-being for any other object breaches both his duty of loyalty to the beneficiary and his duty of prudence in investment. In reviewing the law on these matters, we shall take the conventional law of private trusts as our starting point but pay special attention to the issues that arise under pension trusts.

The essence of the trustee's fiduciary relationship is his responsibility to deal with the trust property "for the benefit of"36 the trust beneficiary. Indeed, in the language of the Restatement (Second) of Trusts, "[t]he trustee is under a duty to the beneficiary to administer

35. See text at Part IIB infra.

36. Restatement (SECOND) OF TRUStS $\$ 2$ (1957) [hereinafter cited as Restatement]. 
the trust solely in the interest of the beneficiary." 37 Although most of the case law applying this duty of loyalty to the beneficiary's interests has arisen in situations of self-dealing or other conflicts of interest in which the courts have acted to prevent the trustee from enriching himself at the expense of the trust beneficiary, ${ }^{38}$ the same result has been reached with regard to fiduciary investments for the benefit of a third party (that is, a party other than the trust beneficiary or the trustee). The Restatement says, in the Official Comment treating the duty of loyalty: "The trustee is under a duty to the beneficiary in administering the trust not to be guided by the interest of any third person." 39 Because the entire object is to protect the trust beneficiary, nothing of principle turns on the identity of the party who profits at his expense.

Blankenship v. Boyle, ${ }^{40}$ decided in 1971, applied the duty of loyalty to social investing. A multi-employer pension fund for coal miners that was dominated by the United Mineworkers Union bought large blocks of shares in certain electric utilities in order to induce their managements to buy union-mined coal. On the complaint of some of the pension-fund beneficiaries, the court enjoined "the trustees from operating the Fund in a manner designed in whole or in part to afford collateral advantages to the Union or the [employers]." 41

The 1974 pension reform law, ERISA, ${ }^{42}$ codified the duty of loyalty in the so-called "sole interest" and "exclusive purpose" rules. ${ }^{43}$ Section 404(a)(1) provides that the "fiduciary shall discharge his duties with respect to a plan solely in the interest of the participants and beneficiaries and ... for the exclusive purpose of providing benefits to participants and their beneficiaries . . ."44

37. Id. at $\S 170$ (1) (emphasis added). 1980).

38. See generally 2 A. Scotr, The LAW OF TRusts $\S \S 170-170.25$ (3d ed. 1967 \& Supp.

39. Restatement, supra note 36 , at $\S 170$, Comment q (emphasis added). See id. at $\S 187$, Comment $g$ (emphasis added):

Improper motive. The court will control the trustee in the exercise of a power where he acts from an improper even though not a dishonest motive, that is, where he acts from a motive other than to further the purposes of the trust. Thus, if the trustee in exercising or failing to exercise a power does so because of spite or prejudice or to further some interest of his own or of a person other than the beneficiary, the court will interpose.

For decisional authority see, e.g., Conway v. Emeny, 139 Conn. 612, 96 A.2d 221 (1953).

40. 329 F. Supp. 1089 (D.D.C. 1971).

41. 329 F. Supp. at 1113.

42. Employee Retirement Income Security Act of 1974, 29 U.S.C. $\$ \S 1001-1381$ (1976).

43. See H.R. REP. No. 533, 93d Cong., 1st Sess. 13, 21, reprinted in [1974] U.S. CoDE CoNG. \& AD. News 4639, 4651, 4659.

44. ERISA \& 404(a)(1), 29 U.S.C. § 1104(a)(1) (1976). 
Another obligation that trust law imposes on fiduciaries is the duty of care defined by the prudent man rule. The case law is now condensed in the Restatement, and effectively codified for pension law in ERISA.45 The Restatement says: "In making investments of trust funds the trustee is under a duty to the beneficiary . . . to make such investments and only such investments as a prudent man would make of his own property having in view the preservation of the estate and the amount and regularity of the income to be derived. . . ."46

Trust law has placed greater emphasis on risk relative to return than the modern theory of finance does, ${ }^{47}$ but risk and return, however weighted, are factors exclusively related to the investor's financial well-being. The highly risk averse investor of traditional trust law accepts a lower return for a lower risk. He does not accept a lower return for some other, nonfinancial purpose. The duty of prudent investing therefore reinforces the duty of loyalty in forbidding the trustee to invest for any object other than the highest return consistent with the preferred level of portfolio risk. ${ }^{48}$

The chief ERISA administrator, Ian D. Lanoff of the Department of Labor, has rejected the suggestion that social investing is not subject to ERISA's rules of prudence and loyalty. He has said that ERISA requires that the fiduciary's "overall investment strategy . . . be designed to protect the retirement income of the plan's participants," and that both the duty of loyalty and the prudent man rule would be violated if a fiduciary were to make an "investment decision based on other objectives, such as to promote the job security of a class of current or future participants." 49 Social factors may be brought in only if it is costless to do so. The Labor Department's approval of the recent Chrysler/UAW agreement endorsing some social investing of pension fund assets was based on the understanding that the investments in question would be "economically competitive with other investment opportunities which may not contain similar socially beneficial features." 50 As previously explained, the field for such costless substitutions is limited because they usually involve added administrative costs and, if attempted on a large scale, would

45. ERISA § 404(a)(1)(B), 29 U.S.C. § 1104(a)(1)(B) (1976).

46. RESTATEMENT, supra note 36 , at $\$ 227$.

47. See Langbein \& Posner, supra note 14, at 3-6.

48. A similar rationale underlies the trustee's familiar duty to invest promptly, in order to make trust funds productive. See Restatement, supra note 36 , at $\$ 181$, Comment c.

49. Lanoff, The Social Investment of Private Pension Plan Assets: May It Be Done Lawfully Under ERISA?, 31 LAB. L.J. 387, 389 (1980).

50. Id at 392 . 
impose on the trust the uncompensated risk that is created by inadequate diversification.

The attorney general of Oregon has issued a formal opinion applying the state's statutory prudent man rule to the question whether investment managers for the state university endowment funds could "take political and moral considerations into account in making investment decisions." He ruled that "[i]t is inappropriate and irrelevant for the investment managers to consider any factors other than the probable safety of, and the probable income from, the investments as required by the statute." Political factors could only be considered to the extent they affected "the safety of or return on investments." 51

There have been two notable efforts to avoid the implications for social investing of the body of fidiciary law that we have just summarized. The distinguished treatise writer, Professor Austin W. Scott, announced his endorsement of social investing in a short statement inserted in the pocket part to his treatise. ${ }^{52}$ And two practicing lawyers, Ronald Ravikoff and Myron Curzan, later undertook a more extensive effort in an article in the California Law Review. ${ }^{53}$

As Ravikoff and Curzan admit, "Scott offers no rationale" and no statutory or decisional authority. ${ }^{54}$ Scott states:

Trustees in deciding whether to invest in, or to retain, the securities of a corporation may properly consider the social performance of the corporation. They may decline to invest in, or to retain, the securities of corporations whose activities or some of them are contrary to fundamental and generally accepted ethical principles. They may consider such matters as pollution, race discrimination, fair employment and consumer responsibility.

$\cdots$

.. . Of course they may well believe that a corporation which has a proper sense of social obligation is more likely to be successful in the long run than those which are bent on obtaining the maximum amount of profits. But even if this were not so, the investor, though a trustee of funds for others, is entitled to consider the welfare of the community, and refrain from allowing the use of the funds in a manner detrimental to society. 55

Scott makes no effort to reconcile his support for social investing

51. 38 OP. OR. ATTY. GEN. No. 7616, at 2 (May 2, 1978), now being litigated in Associated Students of the University of Oregon v. Hunt, No. 78-7502 (Lane County Cir. Ct., filed Nov. 22, 1978).

52. 3 A. Scotr, supra note 38, at $\$ 227.17$ (Supp. 1980).

53. Ravikoff \& Curzan, Social Responsibility in Investment and the Prudent Man Rule, 68 Calif. L. Rev. 518 (1980).

54. Id. at 527 n.31.

55. 3 A. ScotT, supra note 38 , at $\$ 227.17$ (Supp. 1980). 
with the trustee's duties of loyalty and prudence that he canvassed so extensively in the body of his treatise. ${ }^{56} \mathrm{He}$ ignores the ERISA rules, discussed above, that contradict his position. Scott cites some of the literature on corporate social responsibility but does not mention that the legal analysis that has been applied in the corporation cases is the opposite of the rule he is supporting for the law of trusts. The rationale that has protected corporate directors in shareholder suits complaining of acts of seeming corporate altruism is that the directors were in fact pursuing the longer-range self-interest of the firm and hence that their conduct has been wealth-maximizing..$^{57}$

Ravikoff and Curzan take a different approach. They assemble scraps of supposed authority in order to give the appearance that the law of trusts is in flux and is hence no obstacle to their policy preferences. Against the Blankenship case and its uncompromising insistence that an investing strategy that does not seek to maximize the investor's financial well-being breaches the trustee's duty of loyalty to his beneficiaries, Ravikoff and Curzan juxtapose a misreading of Withers v. Teachers' Retirement System. ${ }^{58}$ The Withers case, brought by retirees who were beneficiaries of the New York City schoolteachers' pension fund, Teachers' Retirement System (TRS), challenged the decision of the TRS trustees to purchase $\$ 860$ million of New York City bonds as part of the plan that prevented the city from going bankrupt in late 1975. Like most public employee pension funds, TRS had not been "fully funded." The main asset of TRS was the city's contractual liability to pay benefits out of future tax revenues calculated on past service. City payments to TRS in the 1974 fiscal year constituted sixty-two percent of TRS's total income (as opposed to nine percent derived from employee contributions and twenty-nine percent from investment income). The TRS trustees testified that although the legal situation was far from certain, their best guess was that in the event of bankruptcy essential city services and past city bond debt would have priority over payments to TRS and hence that payments to TRS would cease. In making the loan to the city, the TRS trustees acted in concert with four other municipal employee pension funds, which agreed to purchase $\$ 2.5$ billion in city obligations over a two-and-one-half-year period.

The court upheld the trustees' action, even though the bonds bore such a high risk of default that they would not have satisfied the

56. See 2 A. ScotT, supra note 38, at $\$ \S 170-170.25$ (loyalty); 3 A. Scort, supra note 38, at $\S \S 227-227.16$ (prudent investing).

57. See, e.g., Shlensky v. Wrigley, 95 Ill. App. 2d 173, 180-81, 237 N.E.2d 776, 780 (1968).

58. 447 F. Supp. 1248 (S.D.N.Y. 1978), affd. mem., 595 F.2d 1210 (2d Cir. 1979). 
normal standards of prudent investing (the purchase was also excessive in amount and would have been in breach of the duty to diversify). Ravikoff and Curzan interpret the court's rationale as follows:

Withers may represent an interpretation of the prudent man rule that is quite different from that set forth in Blankenship. Blankenship espouses the traditional conception of the rule: a trustee may not select an investment that fosters nontraditional objectives at the expense of adequate rate of return and corpus safety. In contrast, Withers appears to permit a fiduciary to compromise these traditional objectives in favor of the other goals-at least to some extent. The court upheld the trustees' investment only because the investment gave much-needed aid to the fund's principal contributor and helped to preserve the jobs of fund participants. That is, the investment was prudent in this case because it provided "other benefits." The prudent man standard that emerges from Withers can thusly be cast: a trustee is permitted to sacrifice adequate return and corpus safety only where the investment provides "other benefits" to the interested parties. 59

But what the Withers court actually did was to point to the host of special factors that made the TRS purchase justifiable under the traditional wealth-maximizing standards of trust-investment law. The trustees' "major concern" was "protecting what was, according to the information available to them, the major and indispensable source of TRS's funding - the City of New York," and they "went to great lengths to satisfy themselves of the absence of any reasonable possibility that the City would be able to obtain the needed money from other sources." 60 The trustees used the bond purchase to precipitate federal government financing for New York City, thereby creating for TRS's beneficiaries the prospect of reaching the federal treasury to satisfy the City's liability to TRS. They "obtained a provision conditioning the pension fund's investment in the City bonds on the enactment of federal legislation" providing for interim financing for the City. ${ }^{61}$ Indeed, since the trustees' $\$ 860$ million investment was about what the City would have had to pay TRS over the two-and-a-half-year period in question, TRS "could be no worse off under the plan than it would be in bankruptcy without City funds." 62 The court in Withers endorsed the Blankenship case, and declared that "neither the protection of the jobs of the City's teachers nor the general public welfare were factors which motivated the trustees in their investment decision. The extension of aid to the City was

59. Ravikoff \& Curzan, supra note 53, at 523.

60. Withers v. Teachers' Retirement Sys., 447 F. Supp. 1248, 1252 (S.D.N.Y. 1978), affd. mem., 595 F.2d 1210 (2d Cir. 1979).

61. 447 F. Supp. at 1253.

62. 447 F. Supp. at 1253. 
simply a means - the only means, in their assessment - to the legitimate end of preventing the exhaustion of the assets of the TRS in the interest of all the beneficiaries." 63 The trustees found favor with the court for their effort to protect their greatest asset, which was the liability of the City to pay off its obligations to TRS over future decades.

Ravikoff and Curzan next address ERISA's requirement that pension-fund fiduciaries invest "solely in the interest of the participants and beneficiaries."64 This provision constitutes, as Ravikoff and Curzan correctly observe, "nothing more than a restatement of the common law duty of loyalty."65 Accordingly, they reason, since "[t]he purpose of the duty of loyalty is to require a fiduciary to avoid" self-dealing, social investing is unobjectionable "[a]s long as the fiduciary avoids self-interested transactions ...."66 But the view that the trustee's duty of loyalty governs only in situations of self-dealing is incorrect. To be sure, most people who steal do it for their own gain; that is why most of the case law concerns self-dealing. But, as mentioned earlier, the trustee's duty of loyalty exists solely for the protection of the trust beneficiary, and it is equally violated whether the trustee breaches for the trustee's enrichment or that of a stranger. 67 . Furthermore, many forms of supposed social investing contain overtones of conflict-of-interest or self-dealing: "The legislative history [of ERISA] evinces deep congressional concern not only with conflicts of interest on the part of employers such as investment in employer stock - but also with union selfdealing."68

Regarding ERISA's requirement that the fiduciary invest "for the exclusive purpose of . . . providing benefits to participants and their beneficiaries," 69 Ravikoff and Curzan assert that "[t]he concept of 'benefits' . . . need not be limited to payments that a participant or beneficiary would receive upon retirement, i.e., pure economic return to an investment. It is arguably broad enough to include numerous types of positive returns, e.g., job security and improved working conditions."70 This interpretation of the term "benefits"

63. 447 F. Supp. at 1256 (emphasis added).

64. ERISA \& 404(a)(1), 29 U.S.C. \& $1104(a)(1)$ (1976).

65. Ravikoff \& Curzan, supra note 53, at 531 .

66. Id.

67. See text at note 39 supra.

68. Hutchinson \& Cole, Legal Standards Governing Investment of Pension Assets for Social and Political Goals, 128 U. PA. L. Rev. 1340 (1980).

69. ERISA \& 404(a)(1)(A), 29 U.S.C. \& 1104(a)(1)(A) (1976).

70. Ravikoff \& Curzan, supra note 53, at 532. 
was rejected by the former administrator of the Labor Department's ERISA office, James D. Hutchinson, and a co-author, Charles G. Cole, in an article cited by Ravikoff and Curzan but ignored on the precise question. ${ }^{71}$ Hutchinson and Cole point out that "the term ['benefits'] is used more narrowly throughout [ERISA] to refer to those cash benefits that a participant or his family would receive in accordance with the specifications of the [retirement] plan,"72 and they conclude "that ERISA trusts are to be established and maintained for the limited purpose of providing retirement benefits and not for other, socially desirable purposes which provide collateral or speculative 'benefits' to plan participants or appeal to the philosophical leanings of the plan sponsor or other parties associated with the plan."73

Ravikoff and Curzan avoid the common-law prudent man rule by rewording it to suit their purpose. After quoting the Restatement version of the rule, ${ }^{74}$ they purport to summarize it in a form which changes it radically, and which they thereafter treat as a statement of the law. The objects of the prudent man rule, they say, are "preservation of the trust corpus and attainment of an adequate return."75 The term "adequate" is their own invention, and in thus implying a standard less than "optimal" or "maximum" it is wholly without authority. The authors later endorse a movement from "adequate" to "moderate or even no return,"76 still in the name of prudence.

The trustee's duty to diversify trust investments goes unmentioned in the Ravikoff and Curzan article, although breach of that duty is a main category of potential liability for trustees who engage

71. Ravikoff and Curzan cite the Hutchinson and Cole article as it appeared in EMPLOYEE BENEFIT RESEARCH INSTITUTE, supra note 4, at 27. See Ravikoff \& Curzan, supra note 53, at 531 n. 49. A revised version of the Hutchinson and Cole article has since appeared in the University of Pennsylvania Law Review, cited supra note 68.

72. Hutchinson \& Cole, supra note 68 , at 1370 \& 1371 n. 151.

The only reason that ERISA is less than explicit in defining "benefits" as a strictly economic term is that no other usage even occurred to the draftsmen. In the Congressional findings that constitute the preamble to the statute the term "benefits" is repeatedly used in the conventional and strictly economic sense. "Congress finds ... that despite the enormous growth in [pension and other] plans many employees with long years of employment are losing anticipated retirement benefits owing to the lack of vesting provisions in such plans; that owing to the inadequacy of current minimum standards, the soundness and stability of plans with respect to adequate funds to pay promised benefits may be endangered; that owing to the termination of plans before requisite funds have been accumulated, employees and their beneficiaries have been deprived of anticipated benefits . ..." ERISA \& 2(a), 29 U.S.C. \& 1001(a)(1976) (emphasis added).

73. Hutchinson \& Cole, supra note 68 , at 1371. 520.

74. RESTATEMENT, supra note 36 , at $\$ 227$, quoted in Ravikoff \& Curzan, supra note 53, at

75. Ravikoff \& Curzan, supra note 53, at 520.

76. Id. at 528 . 
in social investing. We have elsewhere suggested that the concept of optimal diversification - as refined in modern capital market theory, the elimination of uncompensated or nonsystematic risk - will come to supply the legal standard of the trustee's duty to diversify.77 If, because of underdiversification, the portfolio incurs a loss compared to an optimally diversified portfolio, this loss would be the measure of the trustee's breach of his duty to diversify and would be recoverable as damages to the beneficiaries at the suit of any of them. For example, with the hypothetical American National Bank socially responsible portfolio discussed earlier, there is a 5\% probability that the portfolio will underperform an optimally diversified portfolio by as much as $4.2 \%$. If the portfolio in fact experienced that loss, it would be the measure of the trustee's liability to the beneficiaries. Of course, the loss could be much greater. There is a $1 \%$ chance that the hypothetical portfolio would underperform an optimally diversified portfolio by $6.3 \%$. Other socially responsible portfolios could involve much larger potential losses, either because they excluded more stocks or because they were less adroit in making compensating portfolio adjustments.

\section{B. A Social-Investing Vehicle for Pension Trusts}

Although neither the common law of trusts nor ERISA, correctly and conventionally understood, permits a trustee to adopt social investment criteria on his own initiative, trust law contains two doctrines, authorization and ratification, that permit the settlor and the beneficiary respectively to waive the ordinarily applicable law and thus to excuse the trustee from what would otherwise be a breach of trust. These doctrines could be employed to authorize social investing for a private trust, and we suggest that ratification gives limited scope to social investing in pension trusts as well.

Authorization. The general rule of trust-investment law is that the settlor may impose on the trust whatever investment policy he sees fit. ${ }^{78}$ There are some rudimentary limits on the settlor's discretion, not well developed in the case law, but in the main he has the same freedom with respect to investment that he has in designating trust beneficiaries. The law seems to have reached this result for two reasons. First, it respects the settlor's property rights, allowing him

77. Langbein \& Posner, supra note 31 , at 27-28, discussing the rule codified in Restatement, supra note 36 , at $\S 228$ : "the trustee is under a duty to the beneficiary to distribute the risk of loss by a reasonable diversification of investments, unless under the circumstances it is prudent not to do so."

78. RESTATEMENT, supra note 36 , at $\$ 164(a)$. 
to extend to his trustee the same power that he himself had to manage his property in an eccentric fashion. Second, the settlor is presumed to know the needs of his beneficiaries better than anyone else. When he insists on the retention of the family farm or the family firm, he is presumed to be acting in the best interest of beneficiaries whom he knows well. That rationale has been carried over to other investment instruments.

Ratification. A trust beneficiary cannot "hold the trustee liable for an act or omission of the trustee as a breach of trust if the beneficiary prior to or at the time of the act or omission consented to it."79 Unless the beneficiary was deceived or acting under an incapacity, he may ratify investment practices that would otherwise be in breach of the trust instrument or of the common law. The idea is that if the beneficiary is entitled to receive and waste the trust funds, he is equally entitled to allow them to be wasted while still in the hands of the trustee.

These waiver-based doctrines become problematic in the multiparty setting of the pension trust. Even in private trust law, the power of one beneficiary to ratify cannot be used to impair the rights of other beneficiaries. The typical pension trust presents the problem not only of multiple beneficiaries but also of multiple settlors - as in multi-employer plans and in so-called contributory plans (where the employee contributes to the fund as well as his employer). Further, the authorization and ratification doctrines presuppose wholly voluntary trusts. In pension trusts, however, employee contributions are often required as a condition of employment; and since in economic terms the employer-paid component is a cost of employment, it too is best understood as a form of involuntary savings whose true cost is borne by the employee. Since the employee is in this important sense the "settlor" of his own pension trust account, there is good reason to prevent plan sponsors (such as employers and/or unions) from using the authorization doctrine to impose social investing upon him.

One of ERISA's innovations was the prohibition against "any provision . . . which purports to relieve a fiduciary from responsibility or liability," 80 and Hutchinson and Cole observe that as a result "the plan documents cannot authorize a policy of social investment that would otherwise be impermissible under the fiduciary standards of the Act." "81 This rule against exculpation clauses eliminates the

79. RESTATEMENT, supra note 36 , at $\$ 216(1)$.

80. ERISA § 410(a), 29 U.S.C. § 1110 (a) (1976).

81. Hutchinson \& Cole, supra note 68 , at 1372 \& 1373-75. 
common-law authorization doctrine from pension trusts, but does not appear to have that effect on the ratification doctrine. Consider a defined-contribution plan, the basic portfolio of which was invested to maximize risk-adjusted return, but in which the individual beneficiary was allowed an election to have his contributions (as well as those made for his account by his employer) invested in an alternative portfolio constructed on social principles. A social-investing option of this sort would seem to fall outside the purpose of the ERISA prohibition. Although the social portfolio would be part of the plan and hence perhaps literally within the scope of ERISA's prohibition on noncomplying portfolios, it would lack that element of involuntary imposition on the beneficiary that motivated the ERISA rule. The beneficiary who knowingly elected the social-investing option and found the market performance of the social fund to be disappointing would be estopped to complain of the imprudence of that social fund.

In a defined-benefit plan, however, a social-investing option seems inapposite. Even when contributory, the distinguishing feature of a defined-benefit plan is that the employer (sometimes a multi-employer group) obliges himself to pay a certain level of retirement benefits to the employee regardless of the investment performance of the fund. If the fund achieves disappointing results, the employer is liable to make up the difference. There is no reason in law to prevent an employer from assuming such a risk on behalf of his willing employees, but he has good reason to resist union or other efforts to induce him to increase his pension costs and liabilities in this way.

It would probably not entail especially significant administrative costs for a pension plan to offer a social-investing option, or indeed more than one, provided that the criteria were identified for the portfolio manager with great precision. Investment professionals tell us that no great expense would be involved in the construction of a portfolio that had relatively mechanical, easy-to-apply criteria for identifying forbidden stocks (for example, $\$ X$ assets in South Africa, $\$ Y$ sales volume in the defense industry, or whatever). This is not to say that such low-administrative-cost criteria would satisfy all or even many advocates of social investing; the point, rather, is that some form of social-investing option could be created that would be consistent with the trust investment law and with ERISA. The plan sponsor would be required to inform beneficiaries about the increased risk and cost of the social portfolio, in order that the choice 
be a truly informed one, and to arrange for confidentiality respecting the portfolio election of each individual, in order to protect beneficiaries from union or other pressures.

Such a social-investing option would be economically sound because the consumption benefits of social investing, which the option would secure, are, in economic analysis, as real as investment benefits. But those who believe that it is sound social policy to discourage individuals from trading future retirement benefits for current consumption will have a ground for continuing to oppose social investing even in the voluntaristic mode that we have endorsed.

\section{UNIVERSITY ENDOWMENTS}

We have thus far considered the social investing question only in the context of the pension fund. The analysis changes when we move from pension trusts to charitable trusts (or to charitable corporations, which for present purposes are indistinguishable from charitable trusts ${ }^{82}$ ). This is an area of considerable consequence for university trustees; they are currently being pressured to apply social criteria to the investment of their endowment funds, and some boards of trustees have succumbed.

The distinguishing juridical feature of the charitable trust is the absence of conventional beneficiaries. A private trust must identify by name or by class the persons who are to take as equitable owners of the trust property, but a charitable trust is void if it is found to serve individual rather than community benefit. ${ }^{83}$ The charitable trust occupies a legally privileged position: it is not subject to the rule against perpetuities; the attorney general or other public officer may enforce it; the cy pres doctrine protects it against ordinary rules of defeasance; and it enjoys a variety of tax and procedural advantages pursuant to statutes that follow the common-law criteria for defining charitable trusts. ${ }^{84}$ The law conditions the grant of these privileges on the requirement of indefiniteness of beneficiaries. A charitable trust will fail if "the persons who are to benefit are not of a

82. See generally 4 A. ScotT, supra note 38 , at $\$ 348.1$.

83. A recent Pennsylvania decision dealing with the claim of the Fraternal Order of Police to be a charitable organization concluded that the group "is essentially a labor organization existing solely for the benefit of its own membership," and hence that "its benefits are not applied for the advantage of an indefinite number of persons as would be the case if the public were to benefit." Commonwealth v. Frantz Advertising, Inc., $23 \mathrm{~Pa}$. Commw. Ct. 526, 533-34, 353 A.2d 492, 496-97 (1976). For a good general background on such cases, see 4 A. ScotT, supra note 38 , at $\S 375.2$.

84. See RESTATEMENT, supra note 36 , at $\$ \$ 365$ (unlimited duration), 391 (public enforcement), 395 (cy pres). 
sufficiently large or indefinite class so that the community is interested in the enforcement of the trust." 85

In place of the definite beneficiaries of private trust law, the law of charitable trusts substitutes the standard of community benefit defined by a circumscribed set of charitable purposes: the relief of poverty; the advancement of religion; the advancement of education and of health (including research); and the promotion of governmental, municipal, and other purposes beneficial to the community. ${ }^{86}$ At the border of each of these categories there can be serious questions about whether particular schemes qualify, but the typical university charter declares purposes that fall unambiguously within the category of education and research (and often within that of health as well).

In analyzing social investing by private and pension trusts, we derived the trustee's obligation to invest for the maximum financial well-being of the trust beneficiaries from the trustee's duties of loyalty and prudent investing; but since, by definition, the charitable trustee does not owe such duties to particular private beneficiaries, the question arises whether there are any legal impediments to social investing of university endowment funds. There are several:

1. Charter. University charters are often granted by special legislative act, both for state schools and private universities. A university may also be chartered under the general nonprofit corporation statute of the jurisdiction. In principle, an authorizing instrument under the common law of trusts would also suffice. Regardless of the form, a university's charter is usually restrictive; it dedicates the institution to educational and related purposes.

A variety of the causes espoused in the name of social investing are not within the purposes of such charters - for example, expressing disapproval of selected foreign governments, or supporting certain labor union organizing campaigns. For university trustees to spend university funds on such causes directly would be ultra vires and put the trustees in breach of their fiduciary duty to the institution. ${ }^{87}$ Were the trustees to pursue the same end by engaging in social investing of the university's endowment funds, they would simply be attempting to do indirectly what they may not do directly.

Under conventional charitable trust law, the state attorney general has standing to sue to prevent such misuses of university endow-

85. Id. at $\S 375$.

86. Id. at $\$ 368$.

87. See id. at $\S 379$. 
ment funds. Because he is a political officer, and there will often be more votes to gain from supporting than from opposing the groups that advocate social investing, his intervention might not always be a serious prospect. We doubt that the attorney general of Connecticut would sue Yale to force it to desist from the sale of shares in companies doing business in South Africa. But the attorney general probably does not have a monopoly of standing in such cases; other persons who have a significant economic interest in the fate of the endowment - for example, professors and students - probably may sue. ${ }^{88}$

2. Noncharitable purposes. If a particular charter is too restrictive to permit a particular scheme of social investing, the proponents of the scheme may reply that the institution ought to get its charter amended. When the charter originates in special state legislation, the legislature can authorize virtually any use of institutional funds (at least as regards the state law of charitable purposes, although not the federal tax consequences). When the charter is nonstatutory and subject to the common law of charitable trusts, valid charter amendments will be impossible for many social investing schemes. The law of charitable trusts denies private autonomy over the definition of what purposes qualify as charitable. The standard of community benefit does not vary with the tastes of universities or their founders, trustees, and donors.

Some of the schemes favored by proponents of social investing are incompatible with these legal standards. In England, a trust for the purpose of changing existing law is not charitable. ${ }^{89}$ Although this rule generally has not been followed in American law, our law does attempt to distinguish between "social" purposes, which are permissible, and "political" purposes, which are not. 90 Trusts to promote socialist political and educational activity have been held not charitable; 91 a similar fate befell a bequest to create an education and information center for the Republican women of Pennsylvania. ${ }^{92}$ A Scottish case held that a trust to support resistance to

88. In Coffee v. William Marsh Rice Univ., 403 S.W.2d 340 (Tex. 1966), two opposing groups of alumni were held to have standing to intervene in a lawsuit in which the trustees of Rice University were seeking the application of the cy pres doctrine in order to eliminate racially restrictive provisions from the trust instrument that had created the school.

89. National Anti-Vivisection Socy. v. Inland Revenue Commrs., [1948] A.C. 31.

90. 4 A. ScotT, supra note 38 , at $\$ 374.6$.

91. See cases in 4 A. ScotT, supra note 38 , at $\$ 374.6$.

92. Deichelmann Estate, 21 Pa. D. \& C.2d 659 (1959). 
strikebreaking and lockouts was political and hence void, ${ }^{93}$ and a New Zealand case ruled similarly against a trust for the League of Nations. ${ }^{94}$ University trustees faced with pressures to adapt their portfolios to the requirements of union organizing campaigns, or some group's foreign-policy views, must beware the force of such precedents. The price of yielding to social investing demands may be litigation costs and potential liability for breach of fiduciary duty.

3. Donors. Past donors - more likely their heirs or successors - may claim that since social investing constitutes a diversion from the educational purposes for which the funds were given, it breaches an implied or express condition and ought to trigger defeasance of the funds in favor of the donor. In Illinois, legislation in force since 1874 denies to universities the "power to divert any gift . . . from the specific purpose designed by the donor."95 Donors would have a strong argument against applying the cy pres doctrine in order to prevent defeasance, since cy pres applies only when it "becomes impossible or impracticable or illegal to carry out the" original charitable purpose. ${ }^{96}$ Thus, trustees who yield to pressures to divert endowment funds from education to other causes are exposing their endowments to the restitutionary claims of donors and heirs.

Trustees must also be concerned with the reaction of future donors. The existence of vigorous competition among universities limits the ability of university administrations to make investment decisions contrary to potential donors' desires in making gifts to universities - their main desire, we assume, being to further educational objectives rather than to foster the political views of those groups that seek to impose social objectives on the university administration. From a practical standpoint, university trustees are also obliged to give full weight to the savings in administrative costs that result when they are spared the endless portfolio reviews and diffcult investment decisions that are involved in social investing, especially in view of the absence of agreement on the social principles to be pursued.

In sum, even though the legal analysis that protects individual beneficiaries against involuntary social investing in the context of private and pension trusts does not govern in the field of charitable trusts with indefinite beneficiaries, much of the economic analysis

93. Trustees for the Roll of Voluntary Workers v. Commissioners of Inland Revenue, [1942] Sess. Cas. 47.

94. In re Wilkinson, [1941] N.Z.L.R. 1065.

95. Ill. Rev. Stat. 1971, ch. 144, \& 1.

96. RESTATEMENT, supra note 36 , at $\$ 399$. 
does apply, and there are serious legal impediments of a different sort to social investing of endowment funds. To be sure, the very competitive pressures we have just described support an argument for a legal rule that would give university trustees the discretion to engage in social investing or not as they see fit. The analogy would be to the business-judgment rule which, as noted earlier, allows corporate directors substantial discretion in determining which business policies to pursue, including those, such as giving to charity, which may seem inconsistent with profit maximization, at least in a narrow, short-run sense. The business-judgment rule is justified by the existence of competitive pressures, in both capital and product markets, that serve as a check against abuse of discretion by business managers; and to the extent that similar pressures operate in the market for education, an analogous grant of discretion to university trustees in fashioning and implementing investment policies for the university's endowment funds could be defended on similar grounds. However, self-perpetuating boards of trustees of nonprofit educational institutions are subject to considerably less intense competitive pressures in both their capital (fund-raising) and their product (the sale of educational services to students in exchange for tuition) markets than are their counterparts in the business sector; and this consideration might argue for some intermediate rule.

Our analysis ends on an uncertain note. There are legal risks to the charitable trustee who fails to try to maximize the value of the charity's endowment fund, but we are not prepared to say that the law does, or should, absolutely forbid social investing by charitable trustees. We go no further than to enumerate the legal risks, affirm that they are substantial ones, and counsel charitable trustees as a matter of prudence to resist to the extent possible the pressures to follow social investing as part of their investment strategy.

In emphasizing the legal risks that university and other charitable trustees incur in pursuing social investing, we do not suggest that the law requires social grievances to go without remedy. The law of charitable trusts has been constructed on the quite intelligent (and efficient) premise that the grand social issues of the day should be resolved in the institutions whose procedures and powers are appropriate to them. The political and legislative process of the modern democratic state is well-adapted to dealing with pressures for social change. Charitable trusts have been designed to serve specialized purposes - in education, healing, the arts, research, and so forth. They are not well suited to be fora for the resolution of complex social issues largely unrelated to their work. There is every reason to 
think that charitable trustees will best serve the cause of social change by remitting the advocates of various social causes to the political arena, where their proposals can be fairly tested and defined, and if found meritorious, effectively implemented. 